\title{
Inventarisasi Tumbuhan Tingkat Pancang dan Semai Berkhasiat Obat di Lembo yang Digunakan oleh Suku Dayak Tunjung Kampung Ngenyan Asa Kecamatan Barong Tongkok Kabupaten Kutai Barat
}

\author{
Eldi Parliansyah ${ }^{1}$, Paulus Matius ${ }^{2}$, Hastaniah ${ }^{3}$ dan Yosep Ruslim ${ }^{4}$ \\ 1,2,3,4 Fakultas Kehutanan, Universitas Mulawarman, Samarinda. \\ 4email: yruslim@fahutan.unmul.ac.id
}

\begin{abstract}
One kind of forest management in a traditional Dayak tribes in West Kutai district is planting various kinds of local fruit which is commonly called lembo. So far, lembo is widely known as a fruit producer, but this study aimed to study utilization of plants that were growing in lembo for traditional medicines. The results, in lembo labakng iweeq and lembo labakng mooq showed that the first location the saplings consisted of 43 species of 22 families and 125,946 individual ha ${ }^{-1}$, and 54 species and 35 families seedlings, with the density were 6,784 individuals $\mathrm{ha}^{-1}$. In the second location, saplings consisted of 33 species and 20 families with the density of 3,961 individual $\mathrm{ha}^{-1}$. Seedlings and understorey plants consisted of 35 species from 25 families with the density were 3,961 individuals ha ${ }^{-1}$ The results of interviews about the use of plants for traditional medicine were found 34 species in 27 plant families that are used to treat 37 kinds of diseases including, Poikilospermum suaveolens (Blume) Merr that is used for treating kidney stone, back pain, cancer, sprue, and weight gain. Eurycoma longifolia Jack used for treating rheumatism, typhoid, lumbago, urination, wound and impotent. Fordia splendissima (Blume ex Miq.) Buijsen were used for animal poisons antidote, food poisoning, powder and healing rituals ceremony. The most common process of plant organs as medicne before consuming were boiled (11 species or $20 \%$ out of all medicinal plant species), directly used were 10 species (19\%), equipment in the healing ritual ceremony were 8 species (15\%).
\end{abstract}

Keywords: Dayak Tunjung tribe, Lembo, Local wisdom, Local fruit, Traditional medicine.

\section{ABSTRAK}

Salah satu cara pengelolaan hutan oleh masyarakat tradisional suku Dayak di kabupaten Kutai Barat adalah dengan menanam berbagai macam tumbuhan buahbuahan lokal yang biasa mereka sebut lembo. Selama ini lembo dikenal luas sebagai penghasil buah-buahan, namun pada penelitian ini bertujuan untuk mempelajari manfaat lain yang dapat diperoleh dari lembo tersebut, yang dalam hal ini adalah pemanfaatan tumbuh-tumbuhan sebagai bahan obat tradisional. Hasil penelitian menunjukkan bahwa, hasil inventarisasi dua lokasi lembo yaitu di lembo labakng iweeq dan lembo labakng mooq, pada lokasi pertama diperoleh tumbuhan tingkat pancang 43 jenis dari 22 famili dengan jumlah individu 1.255 dan dengan kerapatan 125.946 individu ha ${ }^{-1}$, tingkat semai dan tumbuhan bawah 54 jenis dari 35 famili kerapatan 6.784 individu ha $^{-1}$, Pada lokasi kedua diperoleh, tingkat pancang 33 jenis dari 20 famili dengan kerapatan 3.961 individu ha ${ }^{-1}$, semai dan tumbuhan bawah 35 jenis dari 25 famili dengan kerapatan 3.961 individu ha ${ }^{-1}$. Hasil wawancara tentang pemanfaatan tumbuhan sebagai bahan obat tradisional oleh masyarakat ditemukan 34 jenis dalam 27 famili tumbuhan yang dimanfaatkan untuk mengobati 37 macam penyakit diantaranya adalah, Poikilospermum suaveolens (Blume) Merr yang digunakan untuk mengobati kencing batu, sakit pinggang, kanker, sariawan, penambah berat badan. Eurycoma longifolia Jack diginakan untuk mengobati rematik, tipes, sakit pinggang, susah buang air kecil, luka luar dan impoten. Fordia splendissima (Blume ex Miq.) Buijsen digunakan untuk penawar racun binatang, keracunan makanan, bedak dan peralatan dalam ritual pengobatan. Proses pengolahan yang paling banyak dilakukan sebelum pemakaian adalah dengan merebus bagian tumbuhan dan meminumnya 11 jenis (20\%), pemanfaatan bagian 
tumbuhan secara langsung 10 jenis $(19 \%)$, sebagai peralatan dalam ritual pengobatan 8 jenis (15\%).

Keywords: Buah Lokal, Kearifan lokal, Lembo, Obat tradisional, Suku Dayak Tunjung

\section{Pendahuluan}

Pemanfaatan tumbuh-tumbuhan hutan oleh masyarakat lokal merupakan pengetahuan yang sangat penting dalam mempertahankan kelangsungan hidup mereka. Bentuk pemanfaaan tumbuhan dalam kebutuhan sehari-hari sebagai bahan pangan, bahan sandang, bahan obat tradisional, rempah-rempah dan kosmetik serta perlengkapan dalam berbagai upacara tradisional memiliki corak yang berbeda dan khas di setiap daerah (Purwanto, 1998).

Pemanfaatan tumbuhan di lembo atau kebun buah tradisional suku Dayak umumnya hanya sebatas buah-buahan saja (Matius et al., 2014; Matius et al., 2018), sehingga perlu penelitian guna memperoleh pengetahuan tentang manfaat lain yang dapat diperoleh dari lembo. Tujuan penelitian ini adalah untuk mengetahui pemanfaatan tumbuhan sebagai bahan obat tradisional yang digunakan oleh masyarakat Dayak Tunjung sekitar lembo. Melalui teknik pemanenan yang ramah lingkungan juga akan mengurangi kerusakan tegakan tinggal dan pengupasan tanah, sehingga tumbuhan obat yang bermanfaat untuk masyarakat masih banyak yang hidup di lantai hutan (Ruslim, 2011; Ruslim et al., 2016).

Tradisi pengobatan pada suatu kelompok masyarakat tidak terlepas dari kaitan budaya setempat, persepsi mengenai konsep sakit, sehat dan keragaman jenis tumbuhan obat (Garvita, 2015). Cara pengolahan tumbuhan sebagai bahan obat pada setiap daerah di Indonesia memiliki cara yang khas dan diwariskan secara turun temurun, baik itu menggunakan berbagai jenis tumbuhan yang dipercaya dapat menyembuhkan, melalui perantara seorang dukun yang dipercaya memiliki kekuatan tertentu dalam dirinya sehingga dianggap mampu menyembuhkan penyakit atau melalui doa, upacara persembahan dan ritual serta mematuhi segala larangan agar mereka memperoleh keselamatan dan kesehatan dalam hidupnya (Setyowati, 2010).

\section{Metode Penelitian}

Penelitian ini dilakukan di Kampung Ngenyan Asa Kecamatan Barong Tongkok Kabupaten Kutai Barat, pada bulan Agustus sampai dengan November 2018. Metode penelitian ini adalah deskriptif kuantitatif yang berarti memberi gambaran yang lebih rinci mengenai suatu fenomena yang sedang dibahas (Prasetyo dan Jannah, 2015). Pemilihan lokasi Lembo yang diinventarisasi dilakukan secara purposive sampling dan teknik pengumpulan data vegetasi dengan cara pembuatan 5 jalur berpetak, serta pemanfaatan tumbuhan sebagai obat melalui wawancara secara semi structural dan face to face interview serta dokumentasi untuk semua tumbuh-tumbuhan yang ada di kedua lembo tersebut, pemilihan responden secara purposive sampling (Prasetyo dan Jannah, 2014). Responden 
yang diambil sebanyak 15 orang yang dinilai mengetahui pemanfaatan tumbuhan obat secara mendalam untuk tumbuhan yang diambil dari kedua lembo tersebut dan merupakan penduduk asli suku Tunjung yang tinggal di kampung Ngenyan Asa.

\section{Data Inventarisasi}

Data inventarisasi tumbuhan di lembo menggunakan metode garis berpetak, yaitu dengan cara membuat jalur rintisan kemudian pada rintisan tersebut dibuat plot dan sub-plot, untuk pembuatan plot dengan cara melompati satu plot dalam jalur sehingga sepanjang (tumbuhan dengan tinggi di atas $1.5 \mathrm{~m}$ dan diameter setinggi dada kurang dari $10 \mathrm{~cm}$ ) dan sub-plot dengan ukuran $1 \mathrm{~m} \times 1 \mathrm{~m}$ untuk pengukuran tumbuhan tingkat semai (tumbuhan dengan tinggi di bawah $1.5 \mathrm{~m}$ ) dan tumbuhan bawah (Indriyanto, 2015; Ardana, 2012). Banyak dan panjang jalur disesuaikan dengan luas Lembo yang akan diinventarisasi, untuk jumlah plot dan sub plot pada dua lokasi Lembo masing-masing adalah 105 plot, jumah ini diharapkan dapat mewakili keadaan lembo secara umum. Data yang diperoleh kemudian diidentifikasi untuk mengetahui nama lokal dan nama ilmiahnya. Menurut Indriyanto (2015) dan Ardana (2012), metode garis berpetak adalah modifikasi dari metode petak ganda dan metode jalur, yaitu dengan cara membuat jalur rintisan kemudian pada rintisan tersebut dibuat petak, untuk pembuatan petak dengan cara melompati satu petak dalam jalur sehingga sepanjang garis rintis terdapat petak-petak pada jarak tertentu yang sama, bentuk dan ukuran petak-petak pengamatan serta peletakannya pada setiap garis rintis dapat dilihat pada Gambar 1.

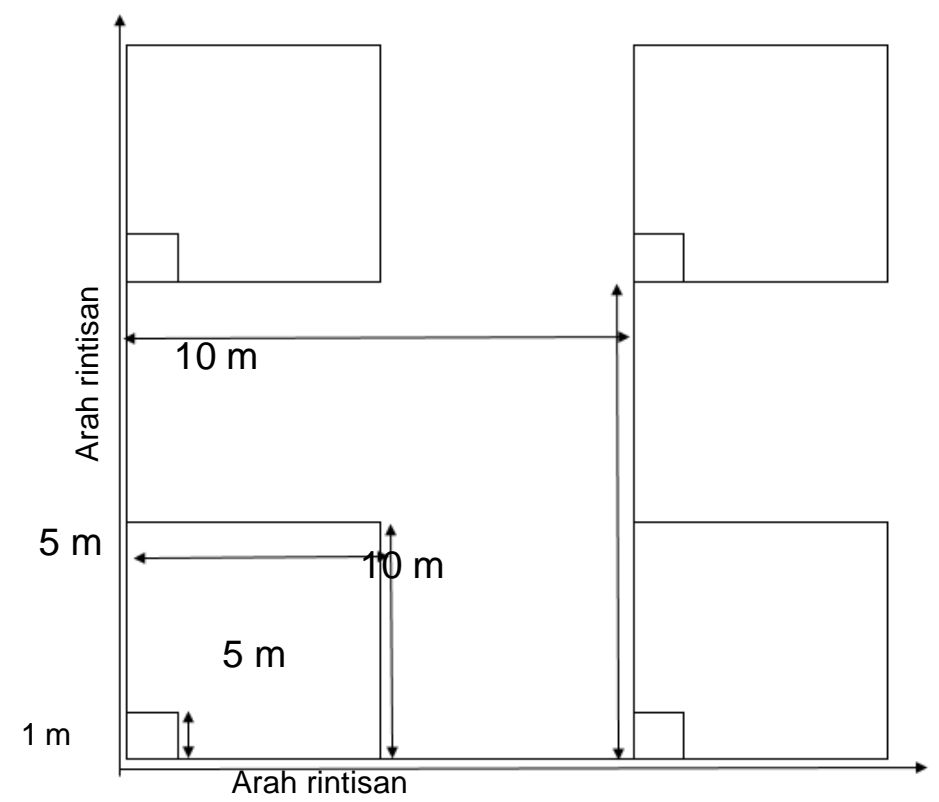

Gambar 1. Bentuk dan penempatan plot dan sub-plot pengamatan pada setiap jalur pengamatan (Fachrul, 2012).

\section{Data pemanfaatan tumbuhan}

Data pemanfaatan tumbuhan yang ditemukan di lembo dilakukan melalui pendekatan emik (metode pendekatan dari sudut pandang suatu kelompok etnis itu sendiri, etik metode pendekatan dari sudut pandang peneliti) dengan cara mewawancarai responden yang dipilih 
dengan pengumpulan data dilakukan dengan wawancara secara semi-terstruktur dan menemui responden secara langsung (Prasetyo dan Jannah, 2014). Dalam penelitian ini diambil secara sensus dikarenakan dalam 2 lokasi penelitian tersebut hanya ditemukan 15 orang yang memahami tentang pemanfaatan tumbuhan sebagai bahan obat tradisional.

\section{Analisis data}

Data inventarisasi yang diperoleh kemudian dihitung kerapatan per hektarnya menggunakan rumus kerapatan (Muller-Dombois dan Ellenberg, 1974; Indriyanto, 2015).

$$
\text { Kerapatan per hektar }=\frac{10.000}{\text { luas plot contoh }} \mathrm{x} \text { jumlah individu }
$$

Untuk mengetahui persentase tumbuhan yang digunakan sebagai bahan obat, bagian tumbuhan yang digunakan, habitus dan cara pengolahan tumbuhan menggunakan rumus berikut.

$$
\text { Jenis tumbuhan obat }=\frac{\text { jumlah jenis tumbuhan obat }}{\text { jumlah jenis tumbuhan yang ditemukan }} \times 100 \%
$$

\section{Hasil dan Pembahasan}

\section{Jenis-jenis tumbuhan yang ditemukan}

Berdasarkan hasil inventarisasi yang telah dilakukan di 2 lokasi yaitu Lembo Labakng Iweeq dan Lembo Labakng Mooq, Kampung Ngenyan Asa ditemukan sebanyak 86 jenis tumbuhan dari 43 famili. Tumbuhan tingkat pancang sebanyak 51 jenis dari 25 famili tumbuhan tingkat semai serta tumbuhan bawah lainnya sebanyak 63 jenis dari 36 famili. Tabel 1 dan 2 dapat diketahui famili tumbuhan yang paling banyak adalah Sapindaceae (8 jenis), Moraceae ( 6 jenis) dan Fabaceae (5 jenis).

\section{Kerapatan jenis tumbuhan}

Berdasarkan hasil penelitian yang dilakukan kerapatan tumbuhan tingkat pancang, semai dan tumbuhan bawah di dua lokasi lembo Kampung Ngenyan Asa, dapat dilihat pada Tabel 3. Dari tabel tersebut dapat diketahui bahwa di Lembo Labakng Iweeq tumbuhan tingkat semai dan tumbuhan bawah ditemukan 54 jenis dari 35 famili dengan jumlah individu sebanyak 932 dan kerapatan 125.946 Individu ha-1 $^{-1}$ pada luas pengamatan 0,0074 ha, tumbuhan tingkat pancang 43 jenis dari 22 famili dengan jumlah individu sebanyak 1.255 dan kerapatan 6.784 individu ha ${ }^{-1}$ pada luas pengamatan 0,185 ha. Lembo Labakng Mooq ditemukan tumbuhan tingkat semai dan tumbuhan bawah sebanyak 35 jenis dari 25 famili dengan jumlah individu 327 dan kerapatan 105.484 Individu ha ${ }^{-1}$ pada luas pengamatan 0,0031 ha, tumbuhan tingkat pancang 33 jenis dari 20 famili dengan jumlah individu 307 dan kerapatan 3.961 Individu ha ${ }^{-1}$ pada luas pengamatan 0,0775 ha.

\section{Persentase tumbuhan yang digunakan sebagai obat}

Dari hasil wawancara yang dilakukan selama penelitian terhadap masyarakat yang tinggal di sekitar lokasi penelitian dari 86 jenis dan dari 43 famili yang ditemukan, terdapat 34 jenis (40\%) dari 27 famili (63\%) tumbuhan yang telah mereka ketahui cara pemanfaatannya untuk pengobatan secara tradisional. Famili tumbuhan yang paling banyak digunakan sebagai 
ISSN 2354-7251 (print)

bahan obat adalah Fabaceae yaitu sebanyak 3 jenis. Pada Gambar 2 diperlihatkan histogram

suku tumbuhan obat yang dimanfaatkan oleh masyarakat. Dari Gambar 2 dapat diketahui

bahwa famili tumbuhan yang paling banyak digunakan sebagai obat adalah Fabaceae ( 3 jenis).

Tabel 1. Jenis dan Famili tumbuhan dari hasil pengamatan di kedua lokasi penelitian (bagian 1)

\begin{tabular}{|c|c|c|c|}
\hline No. & Nama lokal & Nama latin & Famili \\
\hline 1 & Ami & Elipanthus tomentosus Kurz & Euphorbiaceae \\
\hline 2 & Anggrek & Liparis sp. & Orchidaceae \\
\hline 3 & Ayaau & Litsea firma (BI)Hk.f. & Lauraceae \\
\hline 4 & Baloq & Bambusa heterostachya & Poaceae \\
\hline 5 & Bulun sapikng & Rothmannia schoemannii (Teijsm. \& Binn.) Bakh.f. & Rubiaceae \\
\hline 6 & Daraak & Artocarpus dadah Miq. & Moraceae \\
\hline 7 & Deraya bohokng & Horsfieldia grandis (Hk.f.) Warb. & Myristicaceae \\
\hline 8 & Deraya putiq & Horsfieldia wallichii Hook.f. \& Thompson & Myristicaceae \\
\hline 9 & Encamp pajaai & Mangifera pajang Kosterm. & Anacardiaceae \\
\hline 10 & Gai ngenau & Calamus manan Miq & Arecaceae \\
\hline 11 & Gai pelas & Calamus penicillatus Roxb. & Arecaceae \\
\hline 12 & Gai siit & Daemonorops grandis (Giff.) Mart. & Arecaceae \\
\hline 13 & Gaka belokop talutn & Bauhinia semibifida (Roxb.) Benth. & Fabaceae \\
\hline 14 & Gaka berencahai & Fibraurea tinctorial Lour. & Menispermaceae \\
\hline 15 & Gaka beruruuq & Entada phaseoloides (Linne) Merr. & Fabaceae \\
\hline 16 & Gaka bomoi & Smilax setosa Miq. & Smilacaceae \\
\hline 17 & Gaka Bomoi lah & Smilax calophylla L. & Smilacaceae \\
\hline 18 & Gaka kedoot & Spatholobus ferrugineus (Zoll. \& Moritzi) Benth & Leguminosae \\
\hline 19 & Gaka ketatn & Willughbeia coriacea & Apocynaceae \\
\hline 20 & Gaka ketuhai & Indorouchera griffithiana (Planch.) Haillier & Linaceae \\
\hline 21 & Gaka munoong & Fissistigma fulgens (Hook.f \& Thomson) Merr & Annonaceae \\
\hline 22 & Gaka pegesiq & Kunstleria sp. & Fabaceae \\
\hline 23 & Gaka piko & Stenochlaena palustris (Burm. Bedd) & Blechnaceae \\
\hline 24 & Gaka telahat & Ampelocissus ascendiflora Latiff & Vitaceae \\
\hline 25 & Gaka tempera & Tetracera indica (L.) Merr. & Dilleniaceae \\
\hline 26 & Gencilai & Elaeocarpus mastersii King & Elaeocarpaceae \\
\hline 27 & Hentapm & Nephelium ramboutan-ake (Labill.) Leenh. & Sapindaceae \\
\hline 28 & Hojatn & Durio zibethinus Murr & Malvaceae \\
\hline 29 & Hugaaq & Nephelium sp. & Sapindaceae \\
\hline 30 & Ihaau & Dimocarpus logan Lour. & Sapindaceae \\
\hline 31 & Jerikng & Archidendron jiringa (Jack) Nielsen & Fabaceae \\
\hline 32 & Karet & Hevea brasiliensis Muell.Arg & Euphrbiaceae \\
\hline 33 & Kelaer & Strombosia javanica Blume & Olacaceae \\
\hline 34 & Keliwatn & Baccaurea pyriformis Gage & Phyllantaceae \\
\hline 35 & Keni & Garcinia sp. & Clusiaceae \\
\hline 36 & Keramuuq & Dacryodes rostrata (BI.) H.J Lam & Burseraceae \\
\hline 37 & Keranyiiq & Fordia splendissima (Blume ex Miq.) Buijsen & Fabaceae \\
\hline 38 & Kerebumutn & Syzygium lineatum (DC) Merril \& L.M Perry & Myrtaceae \\
\hline 39 & Keremunyikng & Rhodamnia cinerea Jack & Myrtaceae \\
\hline 40 & Lai & Durio kutejensis Hassk. \& Becc. & Malvaceae \\
\hline 41 & Lancikng & Ficus uncinata (King) Becc. & Moraceae \\
\hline 42 & Lehaat & Lansium domesticum Corr. & Maliaceae \\
\hline 43 & Limaat & Castanopsis acuminatissima (BI.) A. DC. & Fagaceae \\
\hline
\end{tabular}


Tabel 2. Jenis dan Famili tumbuhan dari hasil pengamatan di kedua lokasi penelitian (bagian 2)

\begin{tabular}{|c|c|c|c|}
\hline No. & Nama lokal & Nama latin & Famili \\
\hline 1 & Lotokng & Durio oxleyanus Griff. & Malvaceae \\
\hline 2 & Lunuuk & Ficus sp. & Moraceae \\
\hline 3 & Lunuuk dukutn & Poikilospermum suaveolens (Blume) Merr & Urticaceae \\
\hline 4 & Marauleq & Eurycoma longifolia Jack & Simaroubaceae \\
\hline 5 & Meliwe & Polyanthia rumphii (BI.) Merr. & Annonaceae \\
\hline 6 & Meluikng & Scutinanthe brunnea Thw. & Burseraceae \\
\hline 7 & Mentoot & Garcinia sp. & Clusiaceae \\
\hline 8 & Meroah & Garcinia sp. & Clusiaceae \\
\hline 9 & Nakaatn & Artocarpus integer Spreg. & Moraceae \\
\hline 10 & Namuun & Nephelium uncinatum Radlk. & Sapindaceae \\
\hline 11 & Nancakng & Macaranga bancana (Miq.) Mull.Arg & Euphorbiaceae \\
\hline 12 & Natuuq & Palaquium gutta (Hook.) Burck. & Sapotaceae \\
\hline 13 & Ngkapaaq & Asplenium nidus $\mathrm{L}$. & Aspleniaceae \\
\hline 14 & Engkelunau & Macaranga trichocarpa (Reichb.f \& Zoll.) Muell.Arg & Euphorbiaceae \\
\hline 15 & Ngkeronokng & Canarium sp. & Burseraceae \\
\hline 16 & Ngkodooi & Elaeocarpus valetonii Hochr. & Elaeocarpaceae \\
\hline 17 & Ngoiq & Dryobalanops beccarii Dyer & Dipterocarpaceae \\
\hline 18 & Nturui & Artocarpus rigidus Blume. & Moraceae \\
\hline 19 & Nyelutui pukak & Tambernaemontana macrocarpa Jack & Apocynaceae \\
\hline 20 & Paatn & Areca catechu L. & Arecaceae \\
\hline 21 & Pakuq hajiiq & Cycas rumphii Miq. & Cycadaceae \\
\hline 22 & Pegaak & Baccaurea macrocarpa (Miq.) Mull.Arg & Phyllanthaceae \\
\hline 23 & Pelagaq & Schima wallichii (DC) Korth & Theaceae \\
\hline 24 & Pelehet & Psyotria viridiflora Reinw. & Rubiaceae \\
\hline 25 & Peleleq & Lithocarpus gracilis (Korth.) Oerst & Fagaceae \\
\hline 26 & Pengooq & Sarcotheca macrophylla Blume. & Oxalidaceae \\
\hline 27 & Pengoq peai & Galearia fulva (Tul.) Miq. & Pandaceae \\
\hline 28 & Peridakng & Scleria sumatrensis Retz. & Cyperaceae \\
\hline 29 & Puatn & Artocarpus anisophyllus Miq. & Moraceae \\
\hline 30 & Rekeep & Nephelium cuspidatum Blume. & Sapindaceae \\
\hline 31 & Runukng bertiiq & Nephelium lappaceum L & Sapindaceae \\
\hline 32 & Selangkat & Anisophyllea disticha (Jack) Baill. & Anisophylleaceae \\
\hline 33 & Selekoop & Lepisanthes amoena (Hassk.) Leenh. & Sapindaceae \\
\hline 34 & Siwau & Nephelium subfalcatum Radlk. & Sapindaceae \\
\hline 35 & Sp 1 & Anadendrum latifolium Hook. F & Arecaceae \\
\hline 36 & Sp 2 & Alpinia zerumbet (Pers.) B.L. Burtt And R.M Smith & Zingiberaceae \\
\hline 37 & Sp 3 & Scindapsus pictus & Araceae \\
\hline 38 & Sp 4 & Scindapsus sp. & Araceae \\
\hline 39 & Telasaak & Syzygium polyanthum (Wight) Walpers & Myrtaceae \\
\hline 40 & Teliatn & Eusideroxylon zwageri Teysm. \& Binnend. & Lauraceae \\
\hline 41 & Tempegai & Timonius flavescens & Rubiaceae \\
\hline 42 & Terincikng anum & Pandanus sp. & Pandanaceae \\
\hline 43 & Tisiit & Macaranga hullettii King ex. Hook & Euphorbiaceae \\
\hline
\end{tabular}

Tabel 3. Kerapatan tumbuhan tingkat pancang, semai dan tumbuhan bawah di dua lokasi Lembo

\begin{tabular}{lcccccccc}
\hline No. $\begin{array}{l}\text { Lokasi } \\
\text { Penelitian }\end{array}$ & $\begin{array}{c}\text { Jumlah } \\
\text { Jenis }\end{array}$ & $\begin{array}{c}\text { Jumlah } \\
\text { Famili }\end{array}$ & $\begin{array}{c}\text { Semai } \\
\text { Jumlah } \\
\text { Individu }\end{array}$ & $\begin{array}{c}\text { Kerapatan } \\
\text { Indivdu ha- }\end{array}$ & $\begin{array}{c}\text { Jumlah } \\
\text { Jenis }\end{array}$ & $\begin{array}{c}\text { Jumlah } \\
\text { Famili }\end{array}$ & $\begin{array}{c}\text { Jumlah } \\
\text { Individu }\end{array}$ & $\begin{array}{c}\text { Kerapatan } \\
\text { Individu ha-1 }\end{array}$ \\
\hline $\begin{array}{l}\text { Lembo } \\
\text { Labakng } \\
\text { Iweeq }\end{array}$ & 54 & 35 & 932 & 125.946 & 43 & 22 & 1.255 & 6.784 \\
\hline $\begin{array}{l}\text { Lembo } \\
\text { Labakng } \\
\text { Mooq }\end{array}$ & 35 & 25 & 327 & 105.484 & 33 & 20 & 307 & 3.961 \\
\hline
\end{tabular}




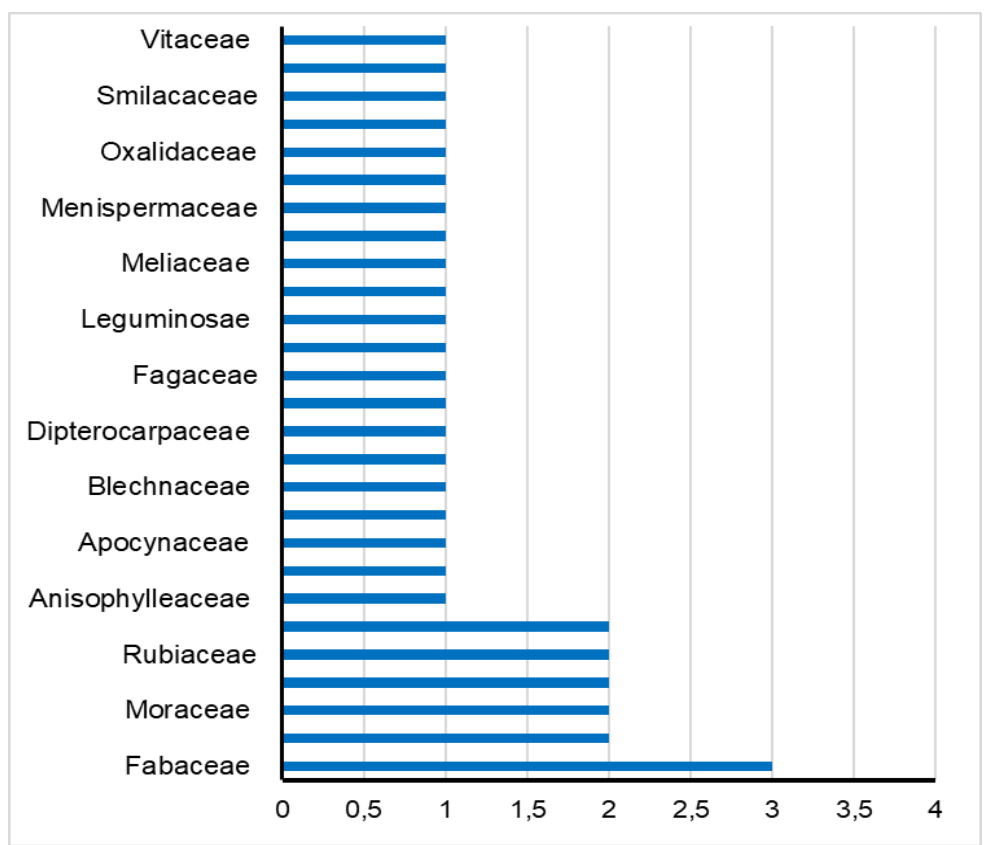

Gambar 2. Histogram jumlah famili dari jenis tumbuhan obat yang dimanfaatkan oleh masyarakat.

Tabel 4. Jenis tumbuhan dan kegunaannya dalam mengatasi ganggunan kesehatan.

\begin{tabular}{|c|c|c|c|}
\hline No & Nama Lokal & Nama Latin & Jenis Penyakit \\
\hline 1 & Ami & Elipanthus tomentosus Kurz & Diabetes \\
\hline 2 & Deraya bohokng & Horsfieldia grandis (Hk.f.) Warb. & Peralatan ritual pengobatan \\
\hline 3 & Deraya putiq & Horsfieldia wallichii Hook.f. \& Thompson & Peralatan ritual pengobatan \\
\hline 4 & Gai pelas & Calamus penicillatus Roxb. & Peralatan ritual pengobatan \\
\hline 5 & Gaka belokop talutn & Bauhinia semibifida (Roxb.) Benth. & Muntah darah \\
\hline 6 & Gaka berencahai & Fibraurea tinctorial Lour. & Hepatitis \\
\hline 7 & Gaka beruruuq & Entada phaseoloides (Linne) Merr. & Penyakit dalam, tipes dan demam \\
\hline 8 & Gaka bomoi & Smilax setosa Miq. & Penyakit dalam dan vitamin rambut \\
\hline 9 & Gaka kedoot & $\begin{array}{l}\text { Spatholobus ferrugineus (Zoll. \& Moritzi) } \\
\text { Benth }\end{array}$ & $\begin{array}{l}\text { Sariawan, kencing batu, maag, disentri dan peralatan } \\
\text { ritual pengobatan }\end{array}$ \\
\hline 10 & Gaka ketuhai & Indorouchera griffithiana (Planch) Haillier & Sakit pinggang \\
\hline 11 & Gaka munoong & $\begin{array}{l}\text { Fissistigma fulgens (Hook.f \& Thomson) } \\
\text { Merr }\end{array}$ & Gatal-gatal \\
\hline 12 & Gaka piko & Stenochlaena palustris (Burm. Bedd) & Lelet atau tomokng \\
\hline 13 & Gaka telahat & Ampelocissus ascendiflora Latiff & Peralatan ritual pengobatan \\
\hline 14 & Gaka tempera & Tetracera indica (L.) Merr. & Kencing batu, kotoran dalam tubuh dan sakit perut \\
\hline 15 & HoJatn & $\begin{array}{l}\text { Durio zibethinus Murr } \\
\text { Fordia splendissima (Blume ex Miq) }\end{array}$ & $\begin{array}{l}\text { Hepatitis } \\
\text { Penawar racun binatang keracunan makanan }\end{array}$ \\
\hline 16 & Keranyiiq & Buijsen & bedak, peralatan ritual pengobatan \\
\hline 17 & Lancikng & Ficus uncinata (King) Becc. & Keputihan dan sakit perut \\
\hline 18 & Lehaat & Lansium domesticum Corr. & Sariawan dan tipes \\
\hline 19 & Limaat & Castanopsis acuminatissima (BI.) A. DC. & Penyakit ginjal dan sakit perut \\
\hline 20 & Lunuuk dukutn & Poikilospermum suaveolens (Blume) & $\begin{array}{l}\text { Kencing batu, sakit pinggang, kanker, sariawan, } \\
\text { penambah berat badan dan batu ginjal }\end{array}$ \\
\hline 21 & Marauleq & Eurycoma longifolia Jack & $\begin{array}{l}\text { Rematik, tipes, sakit pinggang, susah buang air kecil, } \\
\text { luka luar dan impoten }\end{array}$ \\
\hline 22 & Ngkapaaq & Asplenium nidus $\mathrm{L}$. & Peralatan ritual pengobatan \\
\hline 23 & Ngoiq & Dryobalanops beccarii Dyer & Luka bakar \\
\hline 24 & Nyelutui pukak & Tambernaemontana macrocarpa Jack & Kanker \\
\hline 25 & Paatn & Areca catechu L. & Cacingan, panu dan peralatan ritual pengobatan \\
\hline 26 & Pelehet & Psyotria viridiflora Reinw. & Kudis, luka dan peramih \\
\hline 27 & Pengooq & Sarcotheca macrophylla Blume. & Peralatan ritual pengobatan \\
\hline 28 & Puatn & Artocarpus anisophyllus Miq. & Peralatan ritual pengobatan \\
\hline 29 & Runukng bertiiq & Nephelium lappaceum L & Demam \\
\hline 30 & Selangkat & Anisophyllea disticha (Jack) Baill. & Peralatan ritual pengobatan \\
\hline 31 & Selekoop & Lepisanthes amoena (Hassk.) Leenh. & Bedak wajah \\
\hline 32 & Telasaak & Syzygium polyanthum (Wight) Walpers & $\begin{array}{l}\text { Sariawan, tekanan darah tinggi, sakit badan dan } \\
\text { kolesterol }\end{array}$ \\
\hline 33 & Teliatn & Eusideroxylon zwageri Teysm. \& Binnend. & Tipes \\
\hline 34 & Tempegai & Timonius flavescens & Kurap, luka luar dan luka dalam \\
\hline
\end{tabular}




\section{Jenis tumbuhan yang digunakan sebagai obat}

Dari hasil wawancara yang telah dilakukan terhadap masyarakat tentang pemanfaatan tumbuhan lembo sebagai bahan obat dalam mengobati berbagai macam gangguan dapat dilihat pada Tabel 4 .

\section{Cara pengolahan obat}

Hasil penelitian menunjukan bahwa cara pengolahan tumbuhan yang digunakan sebagai bahan obat masih sangat sederhana, baik yang langsung dipakai dalam bentuk segar seperti diminum langsung atau melalui proses terlebih dahulu seperti direbus atau dibakar. Cara pengolahan tumbuhan obat dapat dilihat pada Tabel 5. Sebagian besar masyarakat memanfaatkan tumbuhan melalui berbagai cara. Tumbuhan yang digunakan, bentuk perlakuan yang paling banyak dilakukan sebelum pemakaian adalah dengan merebus bagian tumbuhan dan meminumnya 11 jenis (20\%), pemanfaatan bagian tumbuhan secara langsung 10 jenis (19\%) dan peralatan dalam ritual pengobatan 8 jenis (15\%).

Tabel 5. Cara pengolahan tumbuhan obat

\begin{tabular}{llcc}
\hline No. & Bentuk pengolahan & Jumlah & $\%$ \\
\hline 1 & Rebus + minum & 11 & 20 \\
2 & Diminum & 10 & 19 \\
3 & Peralatan ritual & 8 & 15 \\
4 & Dioles & 6 & 11 \\
5 & Ditempel & 3 & 6 \\
6 & Tumbuk +tempel & 3 & 6 \\
7 & Dimakan & 2 & 4 \\
8 & Dimandikan & 2 & 4 \\
9 & Patung & 2 & 4 \\
10 & Rebus + uap (timu) & 2 & 4 \\
11 & Bakar + oles & 1 & 2 \\
12 & Dibakar & 1 & 2 \\
13 & Jimat & 1 & 2 \\
14 & Serut + minum & 1 & 2 \\
15 & Serut + tempel & 1 & 2 \\
\hline Total & & 54 & 100 \\
\hline
\end{tabular}

\section{Bagian tumbuhan yang digunakan}

Bagian-bagian yang digunakan dapat dipilah menjadi daun, batang, air batang, kulit, akar, air akar, buah atau biji, getah maupun seluruh bagian tumbuhan. Untuk lebih jelasnya dapat dilihat pada Tabel 6. Dari Tabel 6, dapat dilihat bahwa bagian tumbuhan yang paling banyak digunakan sebagai bahan obat adalah daun sebanyak 14 jenis (27\%), air batang 9 jenis $(17 \%)$ dan batang 9 jenis (17\%).

\begin{tabular}{|c|c|c|c|}
\hline No. & Bagian Tumbuhan & Jumlah & $\%$ \\
\hline 1 & Daun & 14 & 27 \\
\hline 2 & air batang & 9 & 17 \\
\hline 3 & Batang & 9 & 17 \\
\hline 4 & Getah & 7 & 13 \\
\hline 5 & Akar & 5 & 10 \\
\hline 6 & Kulit & 5 & 10 \\
\hline 7 & Buah & 2 & 4 \\
\hline \multirow[t]{2}{*}{8} & Umbut & 1 & 2 \\
\hline & Total & 52 & 100 \\
\hline
\end{tabular}




\section{Habitus tumbuhan obat}

Pengelompokan pemanfaatan tumbuhan yang dimanfaatkan sebagai obat juga dapat dikelompokkan berdasarkan habitus tumbuhan tersebut. Untuk lebih jelasnya dapat dilihat pada Tabel 7. Dari Tabel 7, dapat dilihat bahwa habitus tumbuhan yang paling banyak digunakan adalah pohon sebanyak 15 jenis (44\%), liana 12 jenis (35\%), perdu 5 jenis (15\%). Susiarti (2005), terdapat perbedaan dan persamaan dalam jenis-jenis tumbuhan obat yang digunakan oleh masyarakat Dayak Benuaq di Desa Tanjung Isuy, Lempunah, dan Mancong dengan masyarakat Dayak Benuaq di Desa Tanjung Soke dan Gerunggung. Beberapa jenis tumbuhan yang dimanfaatkan sebagai tanaman obat seperti Cassia alata, Callicarpa longifolia, Lansium domesticum, Blumea balsamifera, Brucea javanica, Tinospora crispa, Fordia splendidissima, Hyptis brevipes, dan Clausena excavate. Terdapat perbedaan penyebutan nama daerah, bagian yang digunakan, dan khasiatnya.

Tabel 7. Habitus tumbuhan obat

\begin{tabular}{|c|c|c|c|}
\hline No. & Habitus Tumbuhan & Jumlah & $\%$ \\
\hline 1 & Pohon & 15 & 44 \\
\hline 2 & Liana & 12 & 35 \\
\hline 3 & Perdu & 5 & 15 \\
\hline 4 & Epifit & 1 & 3 \\
\hline 5 & Palm & 1 & 3 \\
\hline Tota & & 34 & 100 \\
\hline
\end{tabular}

Masyarakat yang tinggal di Desa Tanjung Isuy, Lempunah, dan Mancong tumbuhan Blumea balsamifera disebut juga dengan nama lokal mug. Bagian yang sering dimanfaatkan oleh masyarakat adalah daun sebagai obat sakit kepala. Masyarakat Desa Tanjung Soke dan Gerunggung menyebut Blumea balsamifera dengan nama kutai sembung. Masyarakat sering memaanfaatkan bagian akarnya sebagai campuran obat paska persalinan. Cassia alata oleh masyarakat Dayak Benuaq yang tinggal di Desa Tanjung Isuy, Lempunah, dan Mancong disebut dengan nama lokal gerenggang, sedangkan oleh masyarakat sekitar hutan lindung Gunung Beratus disebut gelinggang. Walaupun terdapat perbedaan penyebutan nama daerah, jenis tumbuhan obat tersebut memiliki manfaat yang sama yaitu pucuk daun atau daunnya digunakan sebagai obat gatal, panu, kadas, atau kurap (Falah dkk., 2013).

\section{$4 \quad$ Kesimpulan}

Dari hasil penelitian yang telah dilakukan, ditemukan 51 jenis dari 25 famili tumbuhan tingkat pancang dan 63 jenis dari 36 famili tumbuhan tingkat semai, 34 jenis dari 27 famili tumbuhan yang dimanfaatkan sebagai bahan obat. Berdasarkan habitusnya, pohon 15 jenis, liana 12 jenis, perdu 5 jenis dan epifit serta palm masing-masing 1 jenis, bagian tumbuhan yang dimanfaatkan yaitu, daun yaitu 14 jenis, batang dan air batang masing-masing 9 jenis serta getah 7 jenis, berdasarkan cara pengolahan tumbuhan obat adalah dengan merebus lalu air rebusannya diminum sebanyak 11 jenis, tanpa pengolahan 10 jenis, dan penggunaan bagian tumbuhan melalui proses ritual pengobatan seperti jimat dan patung sebanyak 8 jenis. 
Lembo merupakan kebun tradisional masyarakat Dayak Tunjung yang kaya akan jenis tumbuh-tumbuhan baik budidaya maupun alami, sehingga perlu dilakukan perlindungan dari kepunahan sehingga dianjurkan masyarakat lokal tetap menjaga dan melestarikan kebun tersebut.

\section{Ucapan Terima Kasih}

Pada kesempatan ini para penulis mengucapkan terima kasih yang tak terhingga kepada semua pihak yang telah ikut membantu dalam penelitian ini, khususnya pada Antonius Rudi, Cristianus Renaldy, Yustina Anggraini, Eva Kristina, Rini Krisdayanti Vinsensius Toi dan Siwun yang telah ikut serta dalam pengambilan data di lapangan.

\section{Daftar Pustaka}

Ardhana, I. P. G. (2012). Ekologi Tumbuhan. Denpasar: Udayana University Press.

Mueller-Dombois, D. \& Ellenberg, D. (1974). Aims and methods of vegetation ecology. New York: Wiley.

Fachrul, M. F. (2012). Metode sampling bioekologi. Jakarta: Bumi Aksara.

Falah, F., Sayektiningsih, T., \& Noorcahyati, N. (2013). Keragaman Jenis dan Pemanfaatan Tumbuhan Berkhasiat Obat oleh Masyarakat Sekitar Hutan Lindung Gunung Beratus, Kalimantan Timur. Jurnal Penelitian Hutan Dan Konservasi Alam. https://doi.org/10.20886/jphka.2013.10.1.1-18

Garvita, R. V. (2015). Pemanfaatan Tumbuhan Obat Secara Tradisional Untuk Memperlancar Persalinan Oleh Suku Dayak Meratus Di Kalimantan Selatan. Warta Kebun Raya (Semi-Popular Magazine), 13(2), 51-58.

Indriyanto. (2015). Ekologi hutan. Jakarta: PT. Bumi Aksara.

Matius, P., Setiawati \& Pambudhi, F. (2014). Petunjuk Teknik Pembangunan Kebun Buah-Buahan (Lembo) Oleh Kepala Adat. Samarinda: Pustaka Kajian Perubahan Iklim Universitas Mulawarman (P3I-UM).

Matius, P., Tjwa, S. J. M., Raharja, M., Sapruddin, Noor, S., \& Ruslim, Y. (2018). Plant diversity in traditional fruit gardens (Munaans) of benuaq and tunjung dayaks tribes of West Kutai, East Kalimantan, Indonesia. Biodiversitas. https://doi.org/10.13057/biodiv/d190414

Prasetyo, B., \& Jannah, L. M. (2014). Metode Penelitian Kuantitatif. Jakarta: Rajawali Press. Jakarta.

Purwanto, Y. (1998). Pengobatan Dan Pemanfaatan Sumber Daya Tumbuhan Masyarakat Tinimbar-kei dan Perspektif Ekologinya. Prosiding Seminar Nasional Etnobotani III dengan Tema Kebijakan Masyarakat Lokal Dalam Pengelolaan dan Pemanfaatan Keanekaragaman Hayati Indonesia; 5-6 Mei 1998. Lab. Etnobotani, Balitbang Botani, Puslitbang Biologi, LIPI.

Ruslim, Y. (2011). Penerapan Reduced Impact Logging Menggunakan Monocable Winch. Jurnal Manajemen Hutan Tropika, 17(3), 103-110.

Ruslim, Y., Sihombing, R., \& Liah, Y. (2016). Stand damage due to mono-cable winch and bulldozer yarding in a selectively logged tropical forest. Biodiversitas Journal of Biological Diversity, 17(1), 222-228. 
ISSN 2354-7251 (print)

Susiarti, S. (2005). Indigenous Knowledge on the Uses of Medicinal Plants by Dayak Benuaq, West Kutai, East Kalimantan. Journal of Tropical Ethnobiology, 2(1), 52-64.

Setyowati, F. M. (2010). Etnofarmakologi dan pemakaian tanaman obat suku dayak tunjung di Kalimantan Timur. Media Penelitian dan Pengembangan Kesehatan, 20(3 Sept). 